\title{
Employment Changes in the Sustainable Energy Sector in Scotland
}

World Journal of Science, Technology and Sustainable Development (WJSTSD)

Professor Ronald McQuaid

Stirling Management School, University of Stirling

Stirling FK9 4LA, UK

ronald.mcquaid@stir.ac.uk

and

Dr Ariel Bergman

CEPMLP, University of Dundee, Carnegie Building, Dundee, DD1 4HN, UK e.a.bergmann@dundee.ac.uk

McQuaid, R. and Bergmann, E.A. (2016) 'Employment Changes in the Sustainable Energy Sector in Scotland', World Journal of Science, Technology and Sustainable Development, Vol. 13, 1, pp. - ISSN: 2042-5945 doi:

10.1108/WJSTSD-07-2015-0038 


\section{Structured Abstract}

Purpose This paper considers the development of 'Green' jobs in one region of the European Union, Scotland, where the government has sought to develop renewable and sustainable energy industries and associated employment.

Design/methodology/approach The paper analyses selected secondary data and policy documents and conceptualises issues concerning employment in the renewable energy sector.

Findings It analyses published data and projections on employment in renewable energy sectors, considering the reasons for the lower actual job creation. Many of the jobs in the renewable energy sector are likely to be high-skilled, so there is need to support the development of low-skilled workers and job seekers so that they can enter and progress in the industry. Similarly there is a strong gender bias in the industry which may similarly reduce the entry and retention of the best staff and inhibit social equity.

Research limitations/implications The paper suggests that 'Career first' recruitment and development policies are needed which emphasize improving both productivity and the 'quality' and attractiveness of sustainable, long-term careers in the sector.

Practical implications In addition to relying on general labour attraction policies and separate industry specific skills initiatives for those already in work, more attention needs to be given to developing sustainable employment with career progression for people moving into, or already in, the industry.

Originality/value The links between support for those moving into jobs and developing the skills of existing workers in sustainable industries have been under researched and this paper adds new conceptual developments, in terms of 'Career' first approaches and empirical analysis of employment in renewable industries in Scotland. 


\section{Introduction}

According to the European Environment Agency (EEA, 2014) the move towards a 'Green Economy' is broadly characterized by the objectives of: improving resource-use efficiency (a green economy is one that is efficient in its use of energy, water and other material inputs); ensuring ecosystem resilience (it also protects the natural environment, its ecosystems' structures and flows of ecosystem services); and enhancing social equity (it promotes human well-being and fair burden sharing across societies). 'Green jobs' are seen as a major potential source of employment that is consistent with such a move towards greater environmental, economic and social sustainability. This may also open new opportunities for innovation and entrepreneurship (Ahmed and McQuaid, 2005). This paper considers the development of 'Green' jobs in the renewable energy sector in Scotland, part of the UK where the Scottish Government has sought to develop renewable and sustainable energy industries and associated employment.

There is no agreed definition of 'Green' jobs nor a precise estimate related employment. The European Union (CEC, 2010, 2012; Eurostat, 2009) set out characteristics for 'Green' jobs and take a broad definition with 'Green' jobs “...covering all jobs that depend on the environment or are created, substituted or redefined (in terms of skills sets, work methods, profiles greened, etc.) in the transition process towards a greener economy" (CEC, 2012a) ${ }^{1}$. The UNEP (2008) definition is similarly broad but complementary to this definition².

Much has been written on the potential growth of 'Green' jobs indicates some of the variety of jobs (e.g. skills, timing and number) even within the renewables sector. The European Commission (CEC, 2012a, b) argue that initially high-skilled workers

\footnotetext{
${ }^{1}$ It is estimated that 7.4 million jobs in the EU are in green sectors (renewable energies, energy efficiency, retrofitting, organic agriculture, waste management and recycling) in the EU-27 (CEC, 2013). 2 UNEP (2008, p. 35-6) defines define green jobs as positions in agriculture, manufacturing, construction, installation, and maintenance, as well as scientific and technical, administrative, and servicerelated activities, that contribute substantially to preserving or restoring environmental quality. Specifically, but not exclusively, this includes jobs that help to protect and restore ecosystems and biodiversity; reduce energy, materials, and water consumption through high-efficiency and avoidance strategies; de-carbonize the economy; and minimize or altogether avoid generation of all forms of waste and pollution.
} 
will mainly benefit from the transition towards an economy that is 'greener' and more resource efficient, but more medium-skilled jobs will be created as sustainable manufacturing and services are upgraded, although they note that lower skilled and older workers will fare less well and need to adapt. Hence the issue of training and longer-term career development for low-skilled people already in, or potentially entering, the industry is important.

There have been skills shortages (a lack of available suitable staff to hire) and skills gaps (a lack of skills among existing staff) for installation and manufacturing staff, especially as parts of the processes of both often require the use of new techniques and equipment, and the skills of existing staff are not always used effectively (skills utilisation) (OECD, 2010, 2011; CEDEFOP, 2012; Pearce and Stilwell, 2008; Renewable Energy, 2011). There also remains a gender division with females underrepresented in the industry (ILO, 2011), which industry policies will need to seek to better balance both to attract the best staff and to better achieve social equity goals. Partly in response, within a broader policy framework including the Europe Union's 2020 Strategy and the 7th Environment Action Programme, there have been some support at the EU level for training programmes for skills development in the sector across the entire range of skills: from installers, to maintenance personnel, engineers and public servants (CEC, 2011).

For those with low skills, entry into many "Green' jobs in the renewable energy o other sectors can be difficult. In recent decades, governmental approaches to employment activation policy in the UK and many other countries have been driven by principles of individual skills development with a focus on "Work First" approaches (Lindsay et al., 2007). Moving into work in the sector may not be a "stepping stone" to better employment if the job are low paid or without significant prospects for career progression. However, in some cases the poor types of jobs or job conditions, including in 'Green' jobs, can lead to a cycle of low-pay no-pay leading to work being economically unsustainable. This indicates the need for sustainable, high quality work in order to improve people's situation and if the productive potential of the person is to be realised. Hence the quality of jobs as well as the quantity of 'green' jobs is important. 
Given the heterogeneity in 'Green jobs' or 'Green sectors', it is useful to analyse specific sectors, in the case of this paper we consider the renewable energy section, specifically in Scotland. The next section outlines the context of employment in the renewable energy sector in the EU. Section 3 considers energy development and renewable energy related employment in Scotland. Section 4 considers employment and the industry life cycles and section 5 discusses some related skills issues. Conclusions are then presented.

\section{Employment in the renewable energy sector}

The renewable energy sector is growing quickly, and by 2009/10 there were an estimated 5.0 million jobs globally in renewable energy, which is increasing at 21 per cent per annum (ILO, 2012). Growth is expected across many countries, with, for instance, India projected to increase renewable energy employment from 350,000 in $2009 / 10$ to 1.0 to 1.4 million in 2020 (ILO, 2012, p. 80). It is estimated that 85 percent of today's market for clean energy technologies is in Asia (mainly China) and Europe, the USA being the other main market (EuroObserv'ER, 2012). The main manufacturing exporters are China and the USA (EWEA, 2012).

In the EU (27 countries), renewable energy sectors employed over 1.1 million people in 2010 (25\% higher than in 2009), with 361,360 jobs in Germany, 174,735 in France 108,150 in Italy and only 31,700 jobs in the UK (CEC, 2013). Within this sector, solid biomass contributed an estimated 273,000 direct and indirect full time jobs in 2010, with 268,110 in solar photovoltaic and 253,145 jobs in wind energy, plus an additional 232,050 full time jobs in the insulation industry retrofitting houses. Employment in the renewable energy sector as a percentage share of total employment (15-64 years) varied considerably between countries, but was relatively high in Denmark and Germany, but slightly below the EU average in the UK (Eurobserv'ER, 2014). In the UK there appears to be considerable growth potential, with the Renewable Energy Association (2012), arguably optimistically, estimating that around 400,000 jobs could be supported by the renewables industry by 2020 . 
If an ambitious EU target of $100 \%$ renewable energy by 2050 was to be reached then it is estimated that across the EU there would be 6.1 million jobs in the renewable energy sector by 2050 or 4.4 million in 2030 based on a $45 \%$ renewable energy target (EREC, 2010, 2011). However, from 2010-13 the number employed in renewable energy actually fell by 54,000 , particularly in the photovoltaic industry (EuroObserv'ER, 2014: 134), as employment is heavily tied to the state of the economy, energy policies and subsidies to the sector, so the scale of growth is not guaranteed. Although uncertain, this may be a temporary decline.

Within renewable energy, different forms of energy are associated with different employment generation. For instance, Solar photovoltaic generates over 8.5 job-years per gigawatt hour (GWh), while wind generates just over 1.5 jobs-years per GWh (Wei et al., 2010), so the composition of renewable energies in a region greatly affects employment. This also partly explains why the job decline was relatively high in the photovoltaic industry, as a given decline in capacity growth would have a greater employment impact on it rather than on other forms of renewable energy.

\section{Renewable energy jobs in Scotland}

Government energy policies in the UK have been promoting the move towards a low carbon economy, particularly through generating greater proportions of energy from renewable sources and improving energy efficiency (DECC, 2013), although there are many pathways to achieving this (Foxon, 2013). The Scottish Government (2011) set a target to produce the equivalent of $100 \%$ of the electricity consumed in Scotland by 2020 from renewable sources as part of move to a low carbon society (APS, 2010). Scotland has a devolved government within the United Kingdom, and has limited powers of policy-making and acting on energy issues, but does have specific competency granted over renewable energy, economic development, education and training, agriculture, forestry and fishing, tourism and public transport within Scotland (Scottish Parliament n.d.). The Scottish Government has promoted extensive domestic development of wind energy projects and other technologies like tidal or wave energy projects that it hopes will facilitate Scotland being a world leader in 
research, development, manufacturing, and commercial expertise in this industrial sector.

Scotland has some of the best renewable energy resources in Europe, especially wind, tidal and wave energy (Scottish Executive 2001, 2005) ${ }^{3}$. A major 'wave' of renewable hydro-electricity development occurred in the 1940 to 1960 s, which was followed by the development of North Sea oil production (which started around the 1970s but has been declining since around the turn of the century). Over the last decade, Scotland has been promoting renewable energy industries; especially onshore and offshore wind energy technology. These have considerable potential for long-term regional employment generation (Gilmartin and Allan, 2015).

However, the move towards a 'Green' economy has arguably been disappointing in recent years in terms of the creation of sustainable energy employment in Scotland and the UK. Other countries have had higher relative growth due partly to their greater involvement in different parts of the product cycle of renewable energy technologies (especially manufacturing in Denmark and Germany), and also different energy mixes (e.g. Spain has a greater reliance on solar energy generation, which has greater employment per unit of output, than the UK).

Based on a survey of 541 organisations operating within Scotland, OHC (2014) estimate employment in the renewable energy sector in summer 2013 at 9,272 FTEs (Full Time Equivalents) (see Table 1). This may be a slight underestimate of direct employment in the industry, but while several other studies have been conducted, they were either less extensive, with greater margins of error, or were UK-wide and estimated the Scottish component.

Over half of this employment (54\%) is in the main industrial and population areas the Central Belt of Scotland. The major cities of Scotland lie within this region, except for Aberdeen and Inverness, which are located in the North and Northeast. The Highlands and Islands account for a further $17 \%$ and the North East for $14 \%$ of employment (OHC 2014). In terms of gender $72 \%$ of employment is male and $28 \%$ fe-

\footnotetext{
${ }^{3}$ For a map, see ECMFW wind field data (2000-05) (EEA, 2009, p.14).
} 
male, with one quarter of the survey not providing information on gender. So the gender balance was similar to the wider EU.

The majority of employment occurs in the wind energy subsector $60 \%$ of employment), including onshore wind technology (39\%) and offshore wind technology (21\%). Wave/tidal and bioenergy each employ $9 \%$. In addition, the main industrial city of Glasgow is the most important employment centre for hydroelectric, onshore wind, and electric grid activities and most employment in the largely rural Highlands and Islands is in onshore wind and hydroelectric subsectors. Onshore wind subsector represents 38\% of renewables employment in Glasgow, compared to $60 \%$ in the South of Scotland (290 of 480 FTE) and 32\% in Lothian (which incudes the capital, Edinburgh) (582 of 1,829FTE) ${ }^{4}$. Aberdeen and the North East have the largest concentration of offshore wind employment, followed by Glasgow and Lothian. The concentration of employment in urban areas suggests that rural areas do not receive high levels of long-term employment related economic benefits once construction is completed.

The industry in Scotland was expecting to grow at a rate substantially greater than the economy as a whole with a 20\% increase between 2013 and 2014, but with considerable variation between firms. Over half (54\%) 294 of the 541 employers forecasted they would increase their workforce during the next year by an additional 2,315 FTE workers (OHC, 2014). 42\% of employers forecasted no change in employment levels and $1.9 \%$ forecasted a decrease.

\footnotetext{
${ }^{4}$ Some organisations had multiple locations and it was not possible to allocate employment by region.
} 
Table 1 Employment by region and technology

\begin{tabular}{|c|c|c|c|c|c|c|c|c|c|c|}
\hline Region & $\begin{array}{l}\text { No. of } \\
\text { Organi- } \\
\text { sations }\end{array}$ & $\begin{array}{l}\text { On- } \\
\text { shore } \\
\text { Wind }\end{array}$ & $\begin{array}{l}\text { Off- } \\
\text { shore } \\
\text { Wind }\end{array}$ & $\begin{array}{l}\text { Bioen- } \\
\text { ergy }\end{array}$ & Hydro & $\begin{array}{l}\text { Wave \& } \\
\text { Tidal }\end{array}$ & $\begin{array}{l}\text { Solar, } \\
\text { Heat } \\
\text { Pumps } \\
\text { \& Geo- } \\
\text { thermal }\end{array}$ & Grid & Other & Total \\
\hline $\begin{array}{l}\text { Highlands and } \\
\text { Islands }\end{array}$ & 77 & 405 & 155 & 140 & 311 & 195 & 83 & 4 & 13 & 1,306 \\
\hline Glasgow & 100 & 687 & 297 & 62 & 141 & 215 & 90 & 111 & 206 & 1,809 \\
\hline $\begin{array}{l}\text { North East } \\
\text { Scotland }\end{array}$ & 78 & 244 & 510 & 49 & 34 & 173 & 31 & 25 & 6 & 1,072 \\
\hline $\begin{array}{l}\text { Mid Scotland } \\
\text { and Fife }\end{array}$ & 60 & 160 & 34 & 172 & 59 & 10 & 117 & 7 & 1 & 560 \\
\hline South Scotland & 26 & 290 & 61 & 37 & 13 & 12 & 43 & 2 & 22 & 480 \\
\hline West Scotland & 15 & 75 & 0 & 167 & 4 & 0 & 20 & 0 & 0 & 266 \\
\hline Lothian & 129 & 582 & 297 & 120 & 52 & 185 & 548 & 32 & 13 & 1,829 \\
\hline $\begin{array}{l}\text { Central Scot- } \\
\text { land }\end{array}$ & 23 & 180 & 61 & 63 & 19 & 6 & 12 & 1 & 0 & 342 \\
\hline Not classifiable & 33 & 774 & 427 & 26 & 17 & 10 & 4 & 347 & 3 & 1,608 \\
\hline TOTAL & 541 & 3,397 & 1,842 & 836 & 650 & 806 & 948 & 529 & 264 & 9,272 \\
\hline
\end{tabular}

Source: OHC (2014). 
The sector has significant skills gaps, particularly in construction, technical, and engineering categories (Table 2). The skills shortage (not being able to hire suitably skilled workers) and skills gap (their existing workforces not having adequate skills) was clearly evident and supported the argument that skills remain a major issue for 'Green' industries (see discussion above). The majority $(62 \%)$ of organisations (335 of 541 ) reported skills gaps in at least one of the listed categories (OHC 2014). Often those jobs require graduate level education and organisations appear to have a stronger preference for graduate level personnel than is the case in other similar industries.

Table 2 'Renewables' Skills Gap in Scotland

\begin{tabular}{|l|r|r|r|}
\hline Gap & $\begin{array}{l}\text { Number of } \begin{array}{l}\text { \% of total or- } \\
\text { organisations } \\
\text { citing a gap }\end{array} \\
\text { ganisations } \\
\text { identifying at } \\
\text { least one gap }\end{array}$ & $\begin{array}{l}\text { \% of the tal } \\
\text { respondents in } \\
\text { survey }\end{array}$ \\
\hline Admin - other & 21 & 6.3 & 3.9 \\
\hline Admin - graduate level & 63 & 18.8 & 11.6 \\
\hline Apprenticeships & 2 & 0.6 & 0.4 \\
\hline Communications & 25 & 7.5 & 4.6 \\
\hline $\begin{array}{l}\text { Consultants/senior con- } \\
\text { sultants }\end{array}$ & 21 & 6.3 & 3.9 \\
\hline Graduate level engineers & 116 & 34.6 & 21.4 \\
\hline $\begin{array}{l}\text { Instrumentation and con- } \\
\text { struction engineers }\end{array}$ & 93 & 27.8 & 17.2 \\
\hline Management and leader- \\
ship
\end{tabular}




\begin{tabular}{|l|r|r|r|}
\hline Don't know & 5 & - & 0.9 \\
\hline "No recruitment required" & 194 & - & 35.9 \\
\hline
\end{tabular}

Source: (OHC 2014).

The multiplier effects of employment and expenditure linked to the industry, but not directly within the industry are important. A study for the UK Government study estimated that in 2011 the UK onshore wind subsector had a total direct and supply chain impact of $£ 548$ million in Gross Value Added (GVA) and 8,600 jobs within the UK. £314 million GVA occurred regionally or in the devolved countries within the UK (i.e. Scotland, Northern Ireland, Wales or English regions) from individual wind farms and 4,500 jobs (Biggar Economics, 2012). Also $£ 84$ million GVA and 1,100 jobs were generated from individual wind farms at the local level (i.e. local authority area). Direct onshore wind energy related activities, including the indirect supply chain, had a GVA impact of approximately $£ 66,500$ per annum per FTE job (Scottish Renewables, 2012). It was estimated that approximately six jobs in the supply chain (part of the multiplier effects) were linked to each job in the development category, so there was potential for substantial employment growth. The Scottish Government (2013, p. 131) quoted that "Input-output analysis suggests that for every $£ 100$ million spent on energy-efficiency measures, approximately 1,300 fulltime jobs are supported across the Scottish economy". Scottish Renewables (2012) also estimated that the sector had 11,136 FTE jobs in Scotland in 2011.

\section{Industry and technology life cycles}

Most employment development takes place over two time frames, with the majority during the manufacturing and construction phases of energy projects in the early decades and the remainder during the long-run operation phase (Bergmann, 2014). Many of these jobs are not sustainable if solely based on a regional or even national market size due to the finite number of efficient wind farm sites and intense competition may limit the export opportunities to other regionals or countries. Effectively, there may be technological-geographical 
saturation of the market. After the deployment of projects employment gradually rises, linked to the operation and maintenance of energy facilities. These jobs largely remain, generally for several decades, until the end of the wind farm's life, but the number of jobs remains relatively small when compared to the first phase and the value of the capital assets.

When considering employment and economic growth in the renewable energy industry, it is useful to disaggregate these broad time phases into two industry life-cycle models. First, in the five stage standard model of industry life-cycle the industry evolves through: product research and development; introduction into the economic system; growth and acceptance; maturity; then decline as alternatives arise. In general, much of the renewable energy industry, largely technology-based, is in the first and second stages. However, some parts of the industry, especially those associated with onshore wind energy systems, photovoltaic systems and landfill gas technologies are in the growth stage both globally and in Scotland. The form of these technologies and their products will influence the structure of, and employment in, the firms (Pisano and Teece, 2007).

Second, the life-cycle stage of each of these technologies is important when considering the creation and expansion of renewables and associated income and employment. Each stage has its own impacts on economic development and employment. The five stages are: (1) research and development; (2) planning; (3) construction; (4) operation and maintenance; and (5) decommissioning or repowering. Repowering is the process of replacing older power technology with newer technology and equipment and this can lead to the lifecycle repeating through stages 1 to 5 . In this case the reinvestment and subsequent employment may be more or less than the initial cycle depending on the advancement in technology and learning-by-doing efficiencies that have been created during the previous life cycle. This iteration could continue indefinitely as the technology has limited environmental costs and the "fuel" is a renewable resource within meaningful social, economic and environmental terms. Each phase of the life-cycle is now considered. 
Research and development offers potential for building on regional innovation systems and infrastructure to help ensure wider, longer-term impacts on local economic development (Laurentis, 2012; Kristensen et al., 2015). Research and development is a sustainable activity that provides employment across a range of public, third sector and commercial bodies ranging from very small independent firms to universities and research departments in global corporate with bases in Scotland. There are at least 1,182 FTE working on sustainable energy research in Scottish universities and colleges (OHC, 2014). The level of of R\&D employment in the private sector in Scotland is uncertain. In addition, in 2011 approximately 150 Scottish public sector employees were involved in renewables policy and management activities (Biggar, 2012).

The planning stage prior to the installation of renewable energy, especially windfarms, remains controversial with a range of socio-economic, political and technical barriers to their development (Warren and McFadyen, 2010). Bidwell (2013) argues that support for commercial wind energy depends to a large extent on perceived economic benefits, which are indirectly affected by underlying values, and so a participatory development process is important. Richards et al. (2012) carried out a multi-dimensional approach based on stakeholder's perceptions in Canada and identified a range of underlying sources for the opposition to windfarm development, including knowledge and preferences for the status quo, that need to be addressed to achieve viable solutions.

The planning stage includes project design, environmental studies, legal agreements, project funding and planning permissions. Employment in this stage covers a broad spectrum of highly skilled, and relatively well-paid, workers ranging from lawyers to scientists, financial consultants and planners. The expenditure on these is largely retained in the country, with Biggar (2012) identifying that $98 \%$ of project proposals and planning and development expenditures occurred within the UK.

Construction includes site preparation, manufacturing and the installation of the wind turbines together with connections to the transmission network. The 
balance of plant construction (all of the non-turbine components of a wind farm) creates the most significant opportunities for Scottish companies to participate in the on- and off-shore wind energy subsector (which is the largest related subsector). The UK share of construction expenditures has been approximately $45 \%$ of total project costs over recent years (Biggar, 2012). However, most the turbines have been manufactured outside the UK. Other Europe Union countries (especially Denmark (OECD, 2012) and Germany) dominating the manufacture of turbines installed in the UK. Former turbine fabrication plants in Scotland (e.g. near Macrahannish, Argyll) have closed after some years as production moved to other parts of the foreign-owned parent company with greater economies of scale and other cost advantages.

However, many of the 8,000 components required to manufacture a turbine are produced in the UK and exported to the turbine manufacturers abroad. Several major turbine manufacturers plan to set up parts manufacturing facilities within the UK or have already done so. Generally, manufacturing is high value parts and components that are small to moderate sized, thus facilitating global competition for production as transport of such items is a relatively minor cost. The larger components, such as turbine blades and towers, are the main items constrained by transportation costs and therefore more likely to be produced in Scotland, the UK or elsewhere in the EU. Asian turbine manufacturers often have a large labour costs advantage and Chinese manufacturers have started to capture international market share even with transport costs disadvantages. So, although many economic development and employment benefits from on-site construction work have been gained by Scotland, those form high value added manufacturing have largely not been captured.

European Union regulations prohibit all Member States including the United Kingdom from specifying local content provision of goods or services in all industries, including the sustainable energy sector (or of governments seeking to protect local 'infant industries' as was popular in some countries 50 years ago). This has assisted intra-EU trade and the achievement of economies of scale and the ability of mature and well-established manufacturing firms, e.g. the Siemens, Dong Energy and Vestas companies based on the EU, to suc- 
cessfully enter the Scottish market. The relatively small size of the Scottish market has resulted in few equipment manufacturing firms being established or expanding in Scotland despite the rapidly growing domestic market for wind farm components.

Operation and maintenance incorporates the operation of the energy generation facility and maintaining the turbines and all other assets for the economic life of the project; this is usually 20 to 25 years. This phase involves low levels of economic activity, in regard to the facilities, compared to the construction phase. This stage is significantly different for sustainable energy operations compared to other energy producers, as there is no 'brought in' fuel component to the technology, and no infrastructure or employment from the utilisation of coal, natural gas, and nuclear energy.

Operation and maintenance involves a limited amount of highly skilled labour, while maintenance costs will vary but have been estimated at (WMI, 2015) to average $2 \%-3 \%$ of the original construction cost per annum over the life of a wind farm project, while operational and maintenance costs for onshore wind turbines has been estimated at around $€ 0.012$ to 0.015 per $\mathrm{kWh}$ of wind power produced over the total lifetime of a turbine (EWEA, 2009). Some of the monitoring staff are based abroad, with the maintenance engineers being based more locally. However, on average, for an onshore wind farm some $90 \%$ of maintenance and operation expenditures occur within the region, e.g. within Scotland (Biggar, 2012). Other costs and benefits are difficult to measure such as the opportunity cost of employment that might exist if the other forms of energy generation were maintained. These may also be potential gains or costs to the economy in terms of different energy costs to industrial, household and other users, tax revenue and balance of payments effects. However, Munday et al. (2011) argue that local communities in the UK have in general reaped relatively few economic benefits from windfarms.

Finally, the decommissioning or repowering stage affects all renewable energy projects, as they have a finite life span due to the ageing of the assets, in- 
creased maintenance costs and reducing generating efficiency. Major hydroelectric dams may continue for more than 50 to 100 years before decommissioning, but windfarms are likely to have an economic lifespan of 20-30 years. Each technology has its own life-cycle, although this is influenced by changes in other technologies and costs and developments in the technology itself. Onshore wind has is starting to consider decommissioning, but these older wind turbines are very small relative to current installations, less than $1 \mathrm{MW}$ per turbine in capacity. The large multi-MW turbines will not usually face these questions for at least a decade or more.

An alternative to decommissioning is repowering the wind farm. This involves removing and replacing many components necessary for the operation of a fully functioning facility, which also needs to meet current economic and environmental efficiency standards. Given the sunk costs of infrastructure (such as access roads and power links as well as parts of the turbines given the modular nature of the turbines, this may have considerable economic appeal especially as the wind farm can continue restricted operations while undergoing modernisation and refurbishment.

\section{Skills issues}

The Scottish Government has created specific programmes like The Energy Skills Challenge Fund and the Low Carbon Skills Fund (Scottish Government, 2012; SDS, nd) which have been set up to help provide training for new or transitional workers to join the energy industry workforce. A wide range of training is eligible for support, including: renewable energy, low carbon technologies and micro-generation; energy efficiency, environmental and clean technologies; waste management and re-use; and reducing carbon in supply and energy management.

To attract and retain skilled workers and to upgrade the skills of those in the renewable energy sector, it is important to consider the potential of people being able to have worthwhile careers that they value within the sector. The 
progression of workers in entry-level jobs is constrained by the structure and operation of internal labour markets that limit opportunities for progression (Payne, 2013), so the renewable energy sector should seek to ameliorate these barriers to progression. The quality of 'Green' jobs is an important issue if a range of employed and unemployed people are to enter and be productive in the subsectors (Kalleberg, 2011).

Most research has focused on higher skilled rather than blue-collar workers (Hennequin 2007). There is a need to also consider low-skilled entry-level jobs in terms of their sustainability and progression, as these are more likely to be relevant for the long-term unemployed. The types of jobs or job conditions can lead to a cycle of low-pay no-pay due to work being in most cases economically unsustainable. This indicates the need for sustainable employment if the productive potential of the person is to be realised. "Work first" approaches are concerned with the rapid labour market entry of unemployed people, who are encouraged to take any job as quickly as possible with limited consideration given to the "quality" of employment or its suitability for the individual (Bivand et al., 2006). However, while "Work first" approaches do not prioritise intensive and long-term interventions, such as high quality training, for those facing complex barriers to the labour market (McQuaid and Lindsay, 2005; Lindsay et al., 2007).

The role of employers in the industry is crucial in increasing the investment in skills and career development for workers, especially young workers, for instance through good quality apprenticeships, or women and/or groups such as the unskilled (see for example: European Foundation, 2011; Johnson et al., 2009). Also important when supporting unemployed people is changing the incentives for those who deliver active labour market policies related to 'Green' jobs, so as to take greater consideration of progression after entry into employment and longer-term career progression to better jobs (for those that want progression). Staff in support agencies seeking to recruit people into renewable energy sector must be suitably trained and supported.

Employment policies need to give greater emphasis to a "Career first" ap- 
proach rather than purely a "Work first" approach, as this is likely to lead to more sustainable and productive employment outcomes (McQuaid and Fuertes, 2014). A career includes the person's long-term occupation undertaken together with opportunities for progress, so it includes sustainability in terms of long-lasting employment and opportunities for progress in the occupation. This approach to length of time employed and progression is consistent with other views of sustainable employment, such as that of the UK National Audit Office (2007: 7), who suggest that "having 'sustainable' employment means that an individual remains in work, either in one job or by moving to other jobs; but sustainable employment also means work that provides opportunities to advance and earn more" (p. 7).

A sustainable career ladder is likely to involve people having a skills set, resources and readiness that facilitate long-term employment security, support for skills development, and promotion, but may also include job mobility and moving between employers, with employers helping to improve the employability and careers of employees (Inkson 2006, Ballout 2009, Clarke 2009). It will also encourage a person's own career self-management. Renewable energy organisations need to ensure that their human resources policies and practices fully support this.

More generally, one approach is that of career adaptability, which involves individuals adapting to their social environment and integrating their personal work goals with this. To measure career adaptability, the Career AdaptAbilities Scale uses four scales (concern, control, curiosity and confidence) to reflect resources for managing changes in careers or occupations and other work related issues (Savickas and Porfeli, 2012). A career adaptability competence framework may also assist in helping mid-career workers to make job or career changes (Brown et al. 2013) and move within different parts of the renewable energy sector.

In summary, the promotion of 'Green' jobs, in the renewable energy sector, should be aimed at helping people into 'Green careers' where policies are not primarily concerned with short-term rapid labour market entry of people, but 
also consider significant investments in the human capital of people in or entering the industry, to promote productivity and improve the "quality" of employment and its sustainability.

\section{Conclusions}

'Green' jobs in the renewable energy sector are likely to grow significantly in the future, based upon continued governmental policies and support particularly to reduce carbon use, despite some short-term employment decrease in some parts of the sector. However, many of the jobs are likely to be highskilled, so there is need to support the development of low-skilled workers and job seekers so that they can enter and progress in the industry. Similarly there is a strong gender bias in the industry which may similarly reduce the entry and retention of the best staff and inhibit social equity.

The Scottish Government has pursued a policy of promoting renewable energy based on two key issues: the abundance of renewable energy sources in the country, including wind and water, and the potential employment and economic development linked to the creation of a new and expanding industrial sector. However, the actual job creation has arguably been lower than suggested by the political rhetoric and there has been a lack of monitoring and investigation of the skills needed for the labour force. There have been specialised skills programmes put forward to meet industry needs, although it is too early to evaluate the full effects of these over the long term.

Overall, the development of renewable industries and their equipment and related specialties in Scotland are highly integrated with the European Union. Job creation can be have been seen as happening on two scales; manufacturing promotion within the European Union, and construction and operation/maintenance within the region. There are many opportunities for the future expansion and reconfiguration of renewable energy subsectors but it is crucial that the necessary skills and infrastructure are adequately developed to support this. 
The links between support for those moving into jobs and developing skills existing workers in sustainable industries have been under researched. Rather than relying on general labour attraction policies and separate industry specific skills initiatives for those already in work, more attention needs to be given to developing sustainable employment with career progression for people moving into, or already in, the industry. While there are some specific skills development initiatives by the EU and the Scottish government, there are still major barriers to the sector developing 'Career first' recruitment and development policies which would emphasize improving both productivity and the 'quality' and attractiveness of sustainable, long-term careers in the sector. This suggests that employment policies for low skilled people in or entering the renewables sector need to be reconsidered.

The paper suggests that further research would be useful to consider the differences in different types of 'Green' jobs, for instance those related to energy (generation and reduction in demand) compared to those related to environmental (air, water, land) pollution, material reduction and reuse (recycling). From a policy perspective it would useful to develop better means of employment projection and crucially on how to better develop and match the skills of lower-skilled workers to the higher skilled opportunities offered by renewable energy sectors globally.

\section{References}

Ahmed, A. and McQuaid, R.W. (2005) "Entrepreneurship, Management and Sustainable Development", World Review of Entrepreneurship, Management and Sustainable Development, Vol. 1, No. 1, 6-30.

APS Group (2010) APS Group (2010) A Low Carbon Economic Strategy for Scotland - report for the Scottish Government, Scottish Government, Edinburgh. Available at: www.gov.scot/resource/doc/331364/0107855.pdf (accessed on $27 / 3 / 15$ ) 
Ballout, H.I. (2009) "Career Commitment and Career Success: Moderating Role of Self-Efficacy", Career Development International, Vol. 14, No. 7, pp. $655-670$

Bergmann, E.A. (2014) "What Type of Sustainable Employment arises from Sustainable Energy Development?" in: Larsen C., Rand, S., Schmid, J. and R. Keil (eds), Sustainable Economy and Sustainable Employment, Rainer Hampp Verlag, Munich

Biggar (2012) (Biggar Economics) Onshore Wind Direct \& Wider Economic Impacts, commissioned by UK Department of Environment and Climate Change and Renewables UK. Available at:

https://www.gov.uk/government/publications/onshore-wind-direct-andwider-economic-impacts (accessed on 24/3/2015)

Bivand, P., Brook, B., Jenkins, S. and Simmonds, D. (2006) Evaluation of the StepUp Pilot: Final Report, Research Report No. 337, Department for Work and Pensions, London

Brown, A., Bimrose, J., Barnes, S-A. and Hughes, D. (2012) "The role of career adaptabilities for midcareer changers", Journal of Vocational Behavior, Vol. 80, pp. 754-761

CEC (Commission of the European Community) (2010) Towards a greener labour market - The employment dimension of tackling environmental challenges, CEC, Brussels. Available at:

http://ec.europa.eu/social/main.jsp?catld=370\&langld=en\&featuresld=63\&f urtherFeatures=yes (accessed on 12/5/15)

CEC (2011), Transferability of Skills across Economic Sectors: Role and Importance for Employment at European Level, Luxembourg: Publications Office of the European Union

CEC (2012a), Exploiting the Employment Potential of Green Growth, SWD 92 (final), CEC, Strasbourg. Available at:

http://www.ec.europa.eu/social/BlobServlet?docld=7621\&langld=en (accessed on $12 / 5 / 15)$

CEC (2012b), Towards a job-rich recovery, $\operatorname{COM(2012)} 173$ (final), CEC, Strasbourg. Available at:

http://ec.europa.eu/social/BlobServlet?docld=7619\&langld=en (accessed on $7 / 7 / 15)$ 
CEC (2013), Green Jobs and related policy frameworks. An overview of the European Union, CEC, Brussels. Available at:

http://www.sustainlabour.org/documentos/Green\%20and\%20decent\%20jo bs-\%20An\%200verview\%20from\%20Europe\%20FINAL.pdf (accessed on $12 / 5 / 15)$

CEDEFOP (2012) Green skills and environmental awareness in vocational education and training, Publications Office of the European Union, Luxembourg

Clarke, M. (2009) "Plodders, Pragmatists, Visionaries and Opportunists: Career Patterns and Employability", Career Development International, Vol. 14, No. 1, pp. 8-28

DECC (Department of Energy and Climate Change) (2013) UK Renewable Energy Roadmap: Update 2013. Available at:

https://www.gov.uk/government/uploads/system/uploads/attachment data/f ile/255182/UK Renewable Energy Roadmap - 5 November FINAL DOCUMENT FOR PUBLICATIO .pdf (accessed on 7/7/15)

EEA (European Environment Agency) (2009) Europe's onshore and offshore wind energy potential Technical report No 6/2009, Publications Office of the European Union, Luxembourg. Available at: http://www.eea.europa.eu/publications/europes-onshore-and-offshorewind-energy-potential/at download/file (accessed on 12/5/15)

EEA (2014) Resource-efficient green economy and EU policies, 671 EEA Report, No 2/2014, Publications Office of the European Union, Luxembourg. Available at: http://www.eea.europa.eu/publications/resourceefficientgreen-economy-and-eu/at download/file (accessed on 7/7/15)

EREC (European Renewable Energy Council) (2010) Rethinking 2050. A 100\% Renewable Energy Vision for the European Union, European Renewable Energy Council, Brussels

EREC (2011) $45 \%$ by 2030. Towards a truly sustainable energy system in the EU, Brussels: European Renewable Energy Council. Available at: www.erec.org/fileadmin/erec docs/Documents/Publications/45pctBy2030 ERECReport.pdf (accessed on 12/5/15) 
EurObserv'ER (2012) The State of Renewable Energies in Europe. 11th EurObserv'ER Report. Available at: http://www.eurobserver.org/category/barometer-2011/ (accessed on 12/5/15)

EurObserv'ER (2014) The State of Renewable Energies in Europe. 14th EurObserv'ER Report. Available at: http://www.eurobserver.org/category/barometer-2014/ (accessed on 12/5/15)

European Foundation for the Improvement of Living and Working Conditions (2011) Helping young workers during the crisis: contributions by social partners and public authorities, Publication Office of the European Union, Luxembourg

Eurostat (2009) The environmental goods and services sector: a data collection handbook. Doc. ENV/EXP/WG/07 (2009), Working Group "Environmental Expenditure Statistics" Joint Eurostat/EFTA group Meeting of 25 March 2009

EWEA (European Wind Energy Association) (2009) The Economics of Wind Energy, EWEA, Brussels. Available at:

http://www.ewea.org/fileadmin/files/library/publications/reports/Economics of Wind Energy.pdf (accessed on 7/7/15)

EWEA (2012) Green Growth - The impact of wind energy on jobs and the economy, EWEA, Brussels. Available at:

http://www.ewea.org/fileadmin/files/library/publications/reports/Green Grow th.pdf (accessed on 12/5/15)

Foxon, T.J. (2013) "Transition pathways for a UK low carbon electricity future", Energy Policy, Vol. 52, pp. 10-24

Gilmartin, M. and Allan, G. (2015) "Regional Employment Impacts of Marine Energy in the Scottish Economy: A General Equilibrium Approach", Regional Studies, Vol. 49, No. 2, pp. 337-355

Hennequin, E. (2007) "What 'career success' means to blue-collar workers", Career Development International, Vol. 12, No. 6, pp. 565-581 ILO (International Labour Organization) (2011) Skills For Green Jobs A Global View. Synthesis Report Based On 21 Country Studies, Skills and Employability Department, ILO, Geneva. Available at: http://www.ilo.org/wcmsp5/groups/public/---dgreports/---dcomm/--publ/documents/publication/wcms 159585.pdf (accessed on 12/5/15) 
ILO (2012) Evidence of positive employment effects from green policies, Working Towards Sustainable Development. Opportunities for decent work and social inclusion in a green economy, Available at:

http://www.ilo.org/wcmsp5/groups/public/@dgreports/@dcomm/@publ/doc uments/publication/wcms 181836.pdf (accessed on 12/5/15)

Inkson, K. (2006) "Protean and Boundaryless Careers as Metaphors", Journal of Vocational Behavior, Vol. 69, No. 1, pp. 48-63

Johnson, S., Sawicki, S., C. Pearson, Lindsay, C., McQuaid, R. and Dutton M. (2009) Employee Demand for Skills Development: a Research and Policy Review. Evidence Report 3. UK Commission for Employment and Skills, London

Kalleberg, A.L. (2011) Good Jobs, Bad Jobs: The Rise of Polarized and Precarious Employment Systems in the United States, 1970s to 2000s, Russell Sage Foundation, New York

Kristensen, I., McQuaid, R. and W. Scherrer (2015) "Regional Innovation Policy and Public-Private Partnerships", in: Hilpert, U. (ed.) Handbook on Politics and Technology. London: Routledge

Laurentis, C., D. (2012) "Renewable Energy Innovation and Governance in Wales: A Regional Innovation System Approach", European Planning Studies, Vol. 20, No. 12, pp. 1975-1996.

Lindsay, C., McQuaid, R.W. and Dutton, M. (2007) "New approaches to employability in the UK: combining 'Human Capital Development' and 'Work First' strategies?" Journal of Social Policy, Vol. 36, No. 4, pp. 539-560

McQuaid, R.W. and Lindsay, C. (2005) "The Concept of Employability", Urban Studies, Vol. 42, No. 2, pp. 197-219

McQuaid, R. and Fuertes, V. (2014) "Sustainable integration of the long term unemployed: From Work First to Career First" in: Larsen C., Rand, S., Schmid, J. and R. Keil (eds), Sustainable Economy and Sustainable Employment, Rainer Hampp Verlag, Muenchen, pp. 359-373

Munday, M., Bristow, G. and Cowell, R. (2011) "Wind farms in rural areas: How far do community benefits from wind farms represent a local economic development opportunity?" Journal of Rural Studies, Vol. 27, No. 1, pp. 1 12. 
National Audit Office (2007) Sustainable employment: supporting people to stay in work and advance, The Stationery Office, London Available: www.nao.org.uk/wp-content/uploads/2007/11/070832.pdf (accessed on $12 / 5 / 15)$

OECD (2010) Greening jobs and skills: Labour market implications of addressing climate change, OECD, Paris

OECD (2011) Towards Green Growth, OECD, Paris

OECD (2012) Measuring the Potential of Local Green Growth: An Analysis of Greater Copenhagen, OECD, Paris

OHC (O'Herlihy \& Company, Ltd.) (2014) Employment in Renewable Energy in Scotland 2013, January 2014. Commissioned by Scottish Renewables. Available at: http://www.scottishrenewables.com/publications/employmentrenewable-energy-scotland-2013/ (accessed on 24/3/2015)

Payne, J. (2012) "Fronting-up to skills utilisation: what can the UK learn from Scotland's skills utilisation projects?" Policy Studies, Vol. 33, No. 5, pp. 419-438

Pearce, A. and Stilwell, F. (2008) "Green-collar Jobs: Employment impacts of climate change policies", Journal of Australian Political Economy, Vol. 62, pp. $120-138$

Pisano, G. and Teece, D. (2007) "How to capture value from innovation: Shaping intellectual property and industry architecture", California Management Review, Vol. 50, No. 1, pp. 278-296

Renewable Energy (2011) Working for a Green Britain: Volume 2. Future Employment and Skills in the UK Wind \& Marine Industries, Renewable Energy, London

Renewable Energy Association (2012) Renewable Energy: Made in Britain, REA, London

Richards, G., Noble, B. and Belcher, K. (2012) "Barriers to renewable energy development: A case study of large-scale wind energy in Saskatchewan, Canada", Energy Policy, Vol. 42, pp. 691-698.

Savickas, M.L. and Porfeli, E.J. (2012) "Career Adapt-Abilities Scale: Construction, reliability, and measurement equivalence across 13 countries", Journal of Vocational Behavior, Vol. 80, pp. 661-673 
Scottish Executive (2001) Scotland's Renewables Resource, Volumes I \& II, Garrad Hassan and Partners Limited, Edinburgh. Available at: Volume 1 at http://www.scotland.gov.uk/Resource/Doc/47176/0014634.pdf and Volume 2 at http://www.scotland.gov.uk/Resource/Doc/47176/0014635.pdf (accessed on 24/3/2015)

Scottish Executive (2005) Scotland's Renewable Energy Potential: realising the 2020 target. Available at:

http://www.scotland.gov.uk/Resource/Doc/54357/0013233.pdf (accessed on $24 / 3 / 2015)$

Scottish Government (2011) 2020 Routemap for Renewable Energy in Scotland), Edinburgh, Scottish Government. Available at:

http://www.scotland.gov.uk/Publications/2011/08/04110353/3 (accessed on 24/3/2015)

Scottish Government (2012) 2020 Routemap for Renewable Energy in Scotland) - Update. Available at: www.gov.scot/Resource/0040/00406958.pdf (accessed on 24/3/2015)

Scottish Government (2013) Low Carbon Scotland Meeting the Emissions Reduction Targets 2013-2027, the Second Report. Available at: http://www.gov.scot/Resource/0042/00426134.pdf (accessed on 7/7/2015) Scottish Parliament (n.d.): Devolved and reserved matters explained. Available at: http://www.scottish.parliament.uk/visitandlearn/25488.aspx (accessed on $24 / 3 / 2015$ )

Scottish Renewables (2012): Delivering the Ambition: Employment in Renewable Energy in Scotland

http://www.scottishrenewables.com/publications/employment-renewableenergy-scotland/ (accessed on 24/3/2015)

SDS (Skills Development Scotland) (2014) Low Carbon Skills Fund, SDS, Glasgow. http://www.skillsdevelopmentscotland.co.uk/our-services/lowcarbon-skills-fund/ (accessed on 24/3/2015)

UNEP/ILO/IEO/ITUC (2008), Green Jobs: Towards decent work in a sustainable, low-carbon world; Available at:

http://www.ilo.org/wcmsp5/groups/public/@ed emp/@emp ent/documents/pu blication/wcms 158727.pdf (accessed on 7/7/2015) 
Warren, C.R. and McFadyen, M. (2010) "Does community ownership affect public attitudes to wind energy? A case study from south-west Scotland", Land Use Policy, Vol. 27, No. 2, pp. 204-213.

Wei, M., Patadia, S. and Kammen, D.M. (2010) "Putting renewables and energy efficiency to work: How many jobs can the clean energy industry generate in the US?" Energy Policy, Vol. 38, No. 2, pp. 919-931.

WMI (2015) Operational and Maintenance Costs for Wind Turbines. Available at: $\quad$ http://www.windmeasurementinternational.com/wind-turbines/omturbines.php (accessed on 7/7/2015) 